\title{
Fruit Quality Attributes of New Peach and Nectarine Varieties under Selection in the Ebro Valley Conditions (Spain)
}

C.M. Cantin ${ }^{1}$, J. Torrents ${ }^{2}$, Y. Gogorcena ${ }^{1}$ and M.A. Moreno ${ }^{1}$

${ }^{1}$ Estación Experimental de Aula Dei (CSIC), Dpto. Pomología, Apdo. 202, 50080 Zaragoza, Spain

${ }^{2}$ Agromillora Catalana S.A., El Rebato s/n, 08739 T.M. Subirats, Barcelona, Spain

Keywords: Prunus persica, flowering date, harvesting date, phenolics, antioxidant activity, chilling injury

\begin{abstract}
A breeding program searching for new peach and nectarine varieties adapted to the Ebro Valley growing conditions is being developed at the Aula Dei Experimental Station (CSIC). This program evaluates 15 populations obtained by controlled crosses. Different agronomic parameters such as blooming date, yield, and ripening date were determined in these populations. Quality traits such as fruit type, weight, flesh firmness, soluble solids content (SSC), total phenolics content, antioxidant activity, and other chemical attributes were determined and evaluated. In addition, market life was tested based on chilling injury (CI) susceptibility. Several parameters studied such as yield, SSC, sugars composition, total phenolics, and CI sensibility showed a great variability within the different populations.
\end{abstract}

\section{INTRODUCTION}

Peach is the most important fruit tree species in the world after apple, in terms of annual production (FAOSTAT, 2005). Moreover, peach is the most dynamic species with respect to the appearance of new cultivars in the market (Byrne, 2003; Fideghelli et al., 1998). The long history of peach breeding explains the great diversification of varieties. This situation has produced a large number of available varieties.

Spain is the fourth country in the world in terms of annual yield of peach and nectarine, after China, Italy, and USA (MAPA, 2006). In Spain, the main production areas, located in the Ebro Valley, are Aragón and Cataluña, followed by Murcia.

The lack of experimentation with the new varieties in the fruit growing areas means that the advantages of the new varieties have not been fully explored (Carbó and Iglesias, 2002). On the other hand, European producers shipping within Europe may require three to four weeks of storage. Therefore, understanding and preventing the causes of chilling injury (CI) in peaches and nectarines is of economic, as well as scientific, interest.

The peach and nectarine consumption per capita remains invariable or decreases in most of the European countries. Consumers complain about lack of flavor, problems with the texture, etc. This situation leads to the need of searching for new varieties with high fruit quality that are best adapted to the growing area (Badenes et al., 1999; Jiang et al., 2002).

The main goal of this program is to obtain mid- or late-season varieties with highmedium chilling requirements, good fruit characteristics and best postharvest behaviour (Cantín et al., 2006a, b; Moreno, 2005). Also, a big diversity in fruit type and market availability period is required by international consumer tendencies.

\section{MATERIAL AND METHODS}

Fifteen controlled crosses were made during 2000 and 2001 in collaboration with Agromillora Catalana S.A. Progenies were established during 2001 and 2002 in an experimental orchard at the Experimental Station of Aula Dei. Since 2004, agronomic and fruit quality traits have been evaluated in this material. Flowering time according to Fleckinger (1945), annual yield, and harvesting time were determined in each progeny. 
When the fruit was ripened, yield ( $\mathrm{kg} / \mathrm{tree})$ was measured and a representative fruit sample was taken for the quality evaluations.

Some pomological traits such as fruit type (peach or nectarine, yellow or white flesh), fruit shape, skin blush, or flesh firmness were also scored. The SSC of the juice was measured with a temperature compensated refractometer (model ATC-1, Atago Co., Tokyo, Japan) and the TA (titratable acidity) was measured by titration with $\mathrm{NaOH} 0.1 \mathrm{~N}$ to $\mathrm{pH} 8.1$.

Total soluble phenolic content of methanolic extracts was assayed as described by Cevallos-Casals and Cisneros-Zevallos (2003). Total phenolics were expressed as mg gallic acid equivalent (GA)/100 g fresh weight, based on a standard curve. Antioxidant capacity was adapted from Brand-Williams et al. (1995) using 2,2-diphenyl-1picrylhydrazyl (DPPH) and methanolic extracts, as described by Cevallos-Casals and Cisneros-Zevallos (2003). Change in absorbance at $515 \mathrm{~nm}$ was used and results were expressed as trolox equivalents from a standard curve.

Chilling injury sensibility was evaluated after cold storage at $5^{\circ} \mathrm{C}$ according to Crisosto et al. (1999). After two and four weeks of cold storage, a group of ten fruits from each seedling was ripened (at $20^{\circ} \mathrm{C}$ ) until firmness reached between 10-18 N. Fruit was then evaluated for different manifestations of CI such as lack of juiciness (flesh mealiness), flesh browning, and flesh bleeding. Observations were made on the mesocarp and the area around the pit immediately after the fruit was cut transversally to the plane of the suture. Fruit that had a dry appearance and little or no juice after hand squeezing were considered mealy. Fruit was also informally tasted for a feeling of graininess and/or "off flavors" to corroborate visual mealiness assessment.

\section{RESULTS AND DISCUSSION}

\section{Flowering and Harvesting Dates}

To evaluate flowering date, the average date for each one of the flowering stages was calculated in every progeny. The average harvesting date was also calculated for each progeny (data not shown).

Although flowering and harvest time varied every year depending on the annual temperatures and other factors, we observed that the number of days between flowering and harvest time remained stable for each cross through the three years of this study (Fig. 1). This result confirms that flowering time can be used as estimation for harvesting time. The genetic background of the progeny influences the time needed by the fruit to ripen.

It is worth saying that flowering date was recorded earlier every year with respect to the previous one, which may reflect the effect of global warming in the plant schedule.

\section{Fruit Weight and Yield}

Regarding annual yield, we have found significant differences among the studied populations (Table 1), and among the progenies belonging to the same cross. This result confirms the effect of the genetic background on the fruit yield and allows selecting the most interesting progenies in terms of production.

On the other hand, we have not found any correlation between annual yield and fruit weight, as has been previously reported (Giorgi et al., 2005). In our case, this is probably due to annual fruit thinning.

\section{SSC and TA}

Regarding sugar solids content, significant differences have been found between the different crosses (Table 1). All the genotypes showed values over $10-11^{\circ}$ Brix, which is considered the minimum value for consumer acceptance for yellow flesh peaches and nectarines (Crisosto and Crisosto, 2005; Hilaire, 2003; Kader, 1994). However, the relationship between SSC and consumer acceptance is cultivar specific, and there is not a single reliable SSC that assures a given percentage of satisfied consumers (Crisosto and Crisosto, 2005). The highest value ( $19^{\circ}$ Brix) was recorded by 'Venus' $x$ 'Big Top' 
progenies. They have sub-acid fruits, with high sugar contents and low acidity.

A great variability was also found between the SSC of the progenies belonging to the same cross (data not shown), which can be explained by the quantitative regulation of this quality trait (Dirlewanger et al., 1999; Quilot et al., 2004).

Regarding $\mathrm{pH}$ and TA, significant differences were also found among the different crosses in the study, because it is a cultivar dependent trait (Table 1). However, all the TA values were lower than $0.9 \%$, which is considered the maximum limit for low acidity peaches (Hilaire, 2003). There was no significant interaction between SSC and TA, which agrees with previous reported results (Crisosto and Crisosto, 2005).

\section{Total Phenolics and Antioxidant Activity}

There is a renewed interest in the evaluation of the phenolic content of fruits due to the role they have in the visual appearance, fruit taste, and the important health promoting properties.

Peach fruit is rich in phenolic compounds that are good sources of antioxidants (Byrne, 2002; Tomás-Barberán et al., 2001). Our results show a positive correlation between total phenolics and the antioxidant capacity of the genotypes studied (Fig. 2), suggesting that phenolic compounds significantly contribute to the antioxidant properties of the fruit. Work by Gil et al. (2002) on commercial cultivars of nectarines, peaches, and plums, showed that phenolics were the only compounds that correlated with antioxidant capacity (when compared with vitamin $\mathrm{C}$ and carotenoids). Similar results have also been found in plums and peaches by Cevallos-Casals et al. (2006). These correlations may serve as an important tool for crop breeders to select varieties with phenolic compounds with high antioxidant activity.

\section{Chilling Injury Sensibility}

Peach and nectarine from some cultivars develop lack of juiciness (mealiness), flesh browning, flesh translucency, red pigment accumulation (bleeding), failure to ripen, and flavor loss, after prolonged cold storage and/or after ripening at room temperature (Lurie and Crisosto, 2005). Susceptibility to CI varies according to genetic background (Crisosto et al., 1999). In general, nectarine cultivars are less susceptible to CI than peach cultivars. On the other hand, melting flesh peach cultivars are more susceptible to CI than the firmer non-melting flesh cultivars (Brovelli et al., 1999; Crisosto et al., 1999).

In order to know the genetic influence on this postharvest disorder, we evaluated these CI symptoms in the progenies of 'Venus' $\mathrm{x}$ 'Big Top' (a whole melting nectarine population). A great variability in the sensibility was found among the genotypes studied for mealiness, browning, and bleeding symptoms (Fig. 3). Off flavors were also found in the evaluated fruits. These results corroborate the influence of genetic background on these physiological disorders and the importance of CI sensibility to select new peach and nectarine cultivars.

\section{ACKNOWLEDGMENTS}

Supported by the Spanish Ministry of Education and Science (AGL2002-04219 and AGL2005-05533, co-financed by FEDER), and DGA (A28 and A44) grants. C.M. Cantín was supported by a FPU fellowship from Spanish MEC (co-financed by FSE). We would like to thank Drs. C.H. Crisosto and A. Ibañez for critical reading and correction of this manuscript.

\section{Literature Cited}

Badenes, M., Martínez-Calvo, J., Lorente, M. and Llácer, R.G. 1998. Características del cultivo y la mejora del cultivo del melocotonero en Estados Unidos. Inf. Técn. Econ. Agrar. 94(3):165-176.

Brand-Williams, W., Cuvelier, M.E. and Berset, C. 1995. Use of a free-radical method to evaluate antioxidant activity. Food Sci. Technol. - Lebensm.-Wissens. Technol. 28: 25-30 
Brovelli, E.A., Brecht, J.K., Sherman, W.B. and Sims, C.A. 1999. Anatomical and physiological responses of melting- and non melting-flesh peaches to postharvest chilling. J. Amer. Soc. Hort. Sci. 123:668-674.

Byrne, D.H. 2002. Peach breeding trends. Acta Hort. 592:49-59.

Byrne, D.H. 2003. Breeding peaches and nectarines for mild-winter climate areas: State of the art and future directions. Proc. First Mediterranean Peach Symposium, Agrigento, Italy.

Cantín, C., Torrents, J., Gogorcena, Y. and Moreno, M.A. 2006a. Mejora y selección de nuevas variedades de melocotonero para condiciones del Valle Medio del Ebro. Actas Hortic. 45:209-210.

Cantín, C., Wagner, A., Torrents, J., Gogorcena, Y. and Moreno, M.A. 2006b. Avaliação da qualidade do fruto de novos cultivares de pessegueiro para as condições mediterrâneas. XIX Congresso Brasileiro de Fruticultura, Cabo Frio, Rio de Janeiro.

Carbó, J. and Iglesias, I. 2002. Melocotonero. Las variedades de más interés. Barcelona. Ed: IRTA. p. 287.

Cevallos-Casals, B.A. and Cisneros-Zevallos, L. 2003. Stoichiometric and kinetic studies of phenolic antioxidants from Andean purple corn and red-fleshed sweetpotato. J. Agric. Food Chem. 51:3313-3319.

Cevallos-Casals, B.A., Byrne, D., Okie, W.R. and Cisneros-Zevallos, L. 2006. Selecting new peach and plum genotypes rich in phenolic compounds and enhanced functional properties. Food Chem. 96:273-280.

Crisosto, C.H., Mitchell, F.G. and Ju, Z.G. 1999. Susceptibility to chilling injury of peach, nectarine, and plum cultivars grown in California. HortScience 34:1116-1118.

Crisosto, C.H. and Crisosto, G.M. 2005. Relationship between ripe soluble solids concentration (RSSC) and consumer acceptance of high and low acid melting flesh peach and nectarine [Prunus persica (L.) Batsch] cultivars. Postharvest Biol. Technol. 38:239-246.

Dirlewanger, E., Moing, A., Rothan, C., Svanella, L., Pronier, V., Guye, A., Plomion, C. and Monet, R. 1999. Mapping QTLs controlling fruit quality in peach [Prunus persica (L.) Batsch]. Theor. Appl. Genet. 98:18-31.

FAOSTAT, 2005. http://faostat.fao.org.

Fideghelli, C., Della Strada, G., Grassi, F. and Morico, G. 1998. The peach industry in the world: present situation and trends. Acta Hort. 465:29-40.

Fleckinger, J. 1945. Notations phrénologiques et représentations graphiques du developpment des bourgeons de poiriers. p. 118. In: Congres de Paris de Association française pour l'avancement des Sciences. Paris.

Food and Agricultural Organization. 2006. www.fao.org

Gil, M.I., Tomás-Barberán, F.A., Hess-Pierce, B. and Kader, A.A. 2002. Antioxidant capacities, phenolic compounds, carotenoids, and vitamin C contents of nectarine, peach, and plum cultivars from California. J. Agric. Food Chem. 50:4976-4982.

Giorgi, M., Capocasa, F., Scalzo, J., Murri, G., Battino, M. and Mezzetti, B. 2005. The rootstock effects on plant adaptability, production, fruit quality, and nutrition in the peach (cv. 'Suncrest'). Scientia Hort. 107:36-42.

Hilaire, C. 2003. The peach industry in France: state of art, research and development. p. 27-34. In: F. Marra and F. Sottile (eds.), First Mediterranean Peach Symposium. Agrigento, Italy.

Jiang, Q., Guo, J. and Zhao, J. 2002. Flat peach breeding program in Beijing. Acta Hort. 468:181-186.

Kader, A.A. 1994. Fruit maturity, ripening, and quality relationships. Perishables Handling Newsl. 80,2.

Lurie, S. and Crisosto, C.H. 2005. Chilling injury in peach and nectarine. Postharvest Biol. Technol. 37:195-208.

Ministerio de Agricultura, Pesca y Alimentación. 2006. www.mapa.es.

Quilot, B., Wu, B.H., Kervella, J., Génard, M., Foulongne, M. and Moreau, K. 2004. QTL traits of quality traits in an advanced backcross between Prunus persica cultivars and 
the wild relative species $P$. davidiana. Theor. Appl. Genet. 109:884-897.

Tomás-Barberán, F.A., Gil, M.I., Cremin P, Waterhouse A.L, Hess-Pierce B and Kader A.A. 2001. HPLC-DAD-ESIMS analysis of phenolic compounds in nectarines, peaches and plums. J. Agric. Food Chem. 49:4748-4760.

\section{Tables}

Table 1. Annual yield, SSC, $\mathrm{pH}$ and acidity average of the progenies during the first three bearing years (2005-2007).

\begin{tabular}{|c|c|c|c|c|c|c|c|c|}
\hline Progeny & \multicolumn{2}{|c|}{$\begin{array}{c}\text { Annual yield* } \\
\text { (kg/tree) }\end{array}$} & \multicolumn{2}{|c|}{$\begin{array}{c}\text { SSC } \\
\left({ }^{\circ} \text { Brix }\right)\end{array}$} & \multicolumn{2}{|c|}{$\mathrm{pH}$} & \multicolumn{2}{|c|}{$\begin{array}{c}\text { Acidity } \\
(\text { malic ac } \%)\end{array}$} \\
\hline Andross x Calante & 4.9 & $\mathrm{~h}$ & 12.5 & $\mathrm{~cd}$ & 3.7 & $\mathrm{~cd}$ & 0.55 & hi \\
\hline Andross x Crown Princess & 14.7 & bc & 11.6 & $\mathrm{~d}$ & 3.8 & bc & 0.50 & $\mathrm{i}$ \\
\hline Andross x Rich Lady & 12.7 & $\mathrm{~cd}$ & 11.9 & $\mathrm{~d}$ & 3.8 & $\mathrm{~cd}$ & 0.74 & $\mathrm{c}$ \\
\hline Andross x VAC-9511 & 15.8 & b & 12.2 & $\mathrm{~d}$ & 3.6 & $\mathrm{~cd}$ & 0.61 & fgh \\
\hline Babygold-9 x Crown Princess & 11.0 & de & 10.9 & $\mathrm{~d}$ & 3.8 & $\mathrm{~cd}$ & 0.52 & i \\
\hline Babygold-9 x VAC-9510 & 19.7 & $\mathrm{a}$ & 12.0 & $\mathrm{~d}$ & 3.8 & bc & 0.59 & $\mathrm{gh}$ \\
\hline Mercil x VAC-9512 & 7.6 & fg & 14.9 & $\mathrm{~d}$ & 3.7 & $\mathrm{~cd}$ & 0.67 & cdef \\
\hline Mercil x VAC-9515 & 8.5 & efg & 16.1 & $\mathrm{ab}$ & 3.7 & $\mathrm{~cd}$ & 0.69 & cde \\
\hline Mercil x VAC-9516 & 12.4 & $\mathrm{~cd}$ & 14.9 & $a b$ & 3.9 & bc & 0.63 & efg \\
\hline Orion x VAC-9517 & 12.0 & $\mathrm{~d}$ & 16.1 & $\mathrm{~cd}$ & 3.5 & $\mathrm{~d}$ & 0.73 & cd \\
\hline Red Cal x VAC-9517 & 10.1 & def & 12.7 & $\mathrm{~cd}$ & 3.7 & $\mathrm{~cd}$ & 0.83 & $\mathrm{~b}$ \\
\hline Red Top x VAC-9513 & 7.7 & fg & 11.7 & $\mathrm{~d}$ & 3.9 & $\mathrm{a}$ & 0.63 & efg \\
\hline Rich Lady x VAC-9511 & 6.2 & $\mathrm{gh}$ & 11.9 & $\mathrm{~d}$ & 3.6 & $\mathrm{~cd}$ & 0.82 & $\mathrm{~b}$ \\
\hline VAC-9512 x VAC-9511 & 6.8 & gh & 15.0 & $\mathrm{bc}$ & 3.6 & $\mathrm{~cd}$ & 0.83 & $\mathrm{a}$ \\
\hline Venus x Big Top & 6.0 & gh & 18.9 & $\mathrm{a}$ & 3.8 & bc & 0.66 & def \\
\hline
\end{tabular}

Means followed by a different letter within a column are significantly different $(\mathrm{P} \leq 0.05)$. 


\section{Figures}

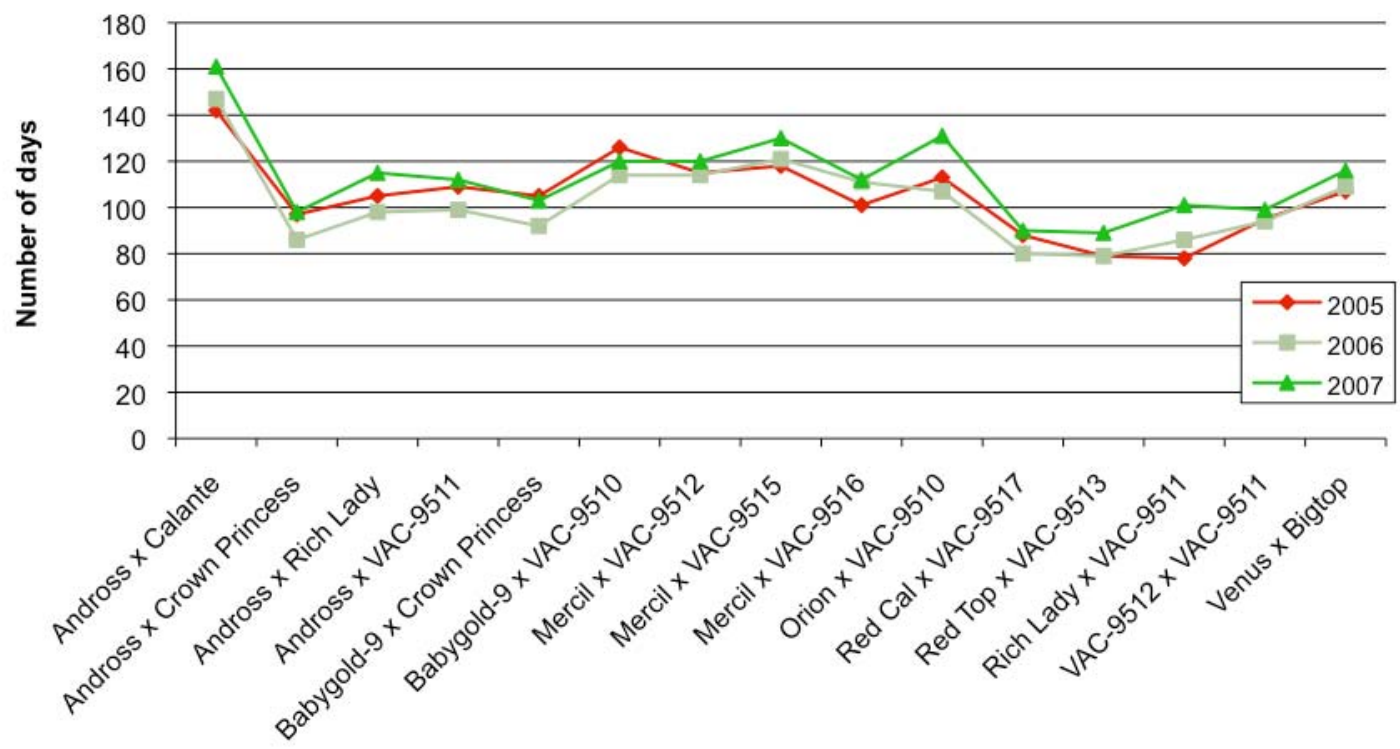

Fig. 1. Number of days between flowering and harvesting date on the different progenies through the first three bearing years.

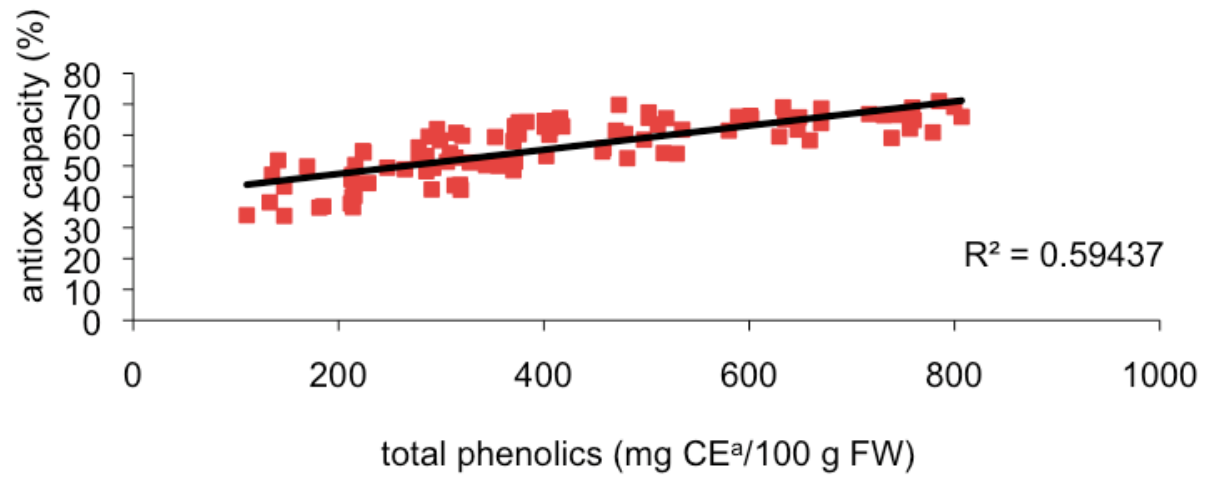

Fig. 2. Total phenolics content and antioxidant capacity correlation in the studied genotypes $(\mathrm{P} \leq 0.05) .{ }^{\mathrm{a}} \mathrm{CE}$ catechin equivalents. 


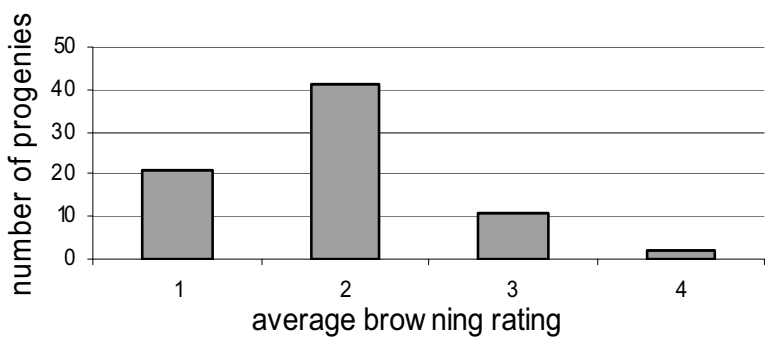

a

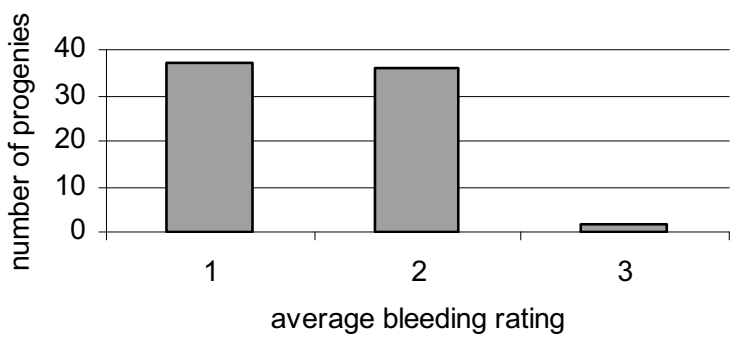

b

c

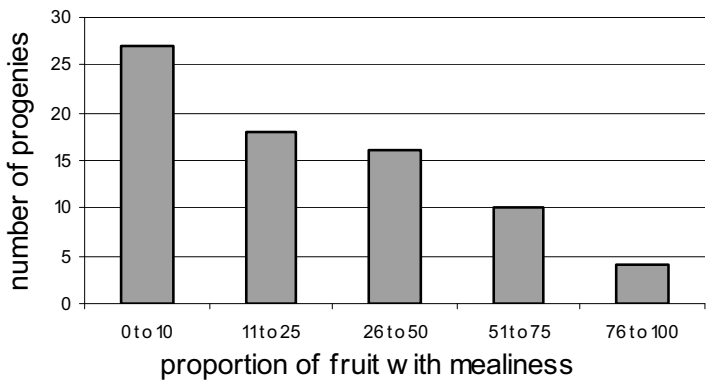

Fig. 3. Segregation of chilling injury symptoms in 'Venus' $x$ 'Big Top' progenies: a) browning, b) bleeding, and c) mealiness. 